\title{
Discrimination of forest species using medium spatial resolution images
}

\author{
Carla Talita Pertille $\circledast^{1 *}$ Marcos Felipe Nicoletti $\circledast^{2}$
}

${ }^{1}$ Universidade do Estado de Santa Catarina, Av. Luis de Camões, 2090, Conta Dinheiro, CEP 88520-000, Lages, SC, Brasil ${ }^{2}$ Universidade do Estado de Santa Catarina, Av. Luis de Camões, 2090, Conta Dinheiro, CEP 88520-000, Lages, SC, Brasil

\begin{abstract}
Original Article
*Corresponding author: carlatpertille@gmail.com

Keywords:

Remote Sensing

Vegetation index

Forest species

Palavras-chave:

Sensoriamento Remoto

Índices de vegetação

ABSTRACT: This research aimed to evaluate the potential of orbital images from the Landsat-8/OLI and Sentinel-2 /MSI sensors in the distinction of species from a forest stand located in Campo Belo do Sul, State of Santa Catarina, Brazil. A total of 53 plots were allocated in the field, in which the central coordinate of the plot was collected using GPS receivers. In SIG environment, two images were used, one from each sensor, closely dated to the field campaign and with no clouds and other atmospheric factors. Then, the images were processed, and 17 vegetation indexes were calculated for each one. The indices were compared statistically by the t-Student test for independent samples. The indices that provided the best species differentiation were: CRI, GNDVI, NDI11, NDI12, NDVI, RDVI, SAVI, and SR. In addition, the species with greater prominence in the Landsat-8/OLI images was Eucalyptus spp. whereas Cunninghamia lanceolata (Lamb.) Hooker was easily distinguished in Sentinel-2 images. It was possible to differentiate the species from remote data derived from the Sentinel-2/MSI and Landsat-8/OLI sensors. However, further studies using other Remote Sensing data sources and other species are suggested.
\end{abstract}

Espécies florestais

Received in

2021/05/06

Accepted on

$2021 / 20 / 10$

Published in

2021/12/30

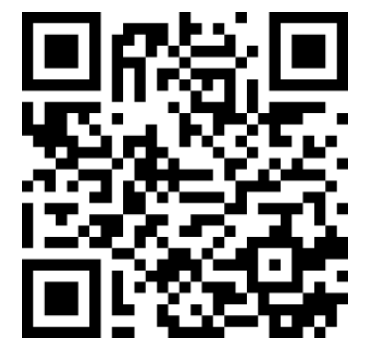

DOI: http://dx.doi.org/ 10.34062/afs.v8i3.12525

\section{(cc) BY}

\section{Discriminação de espécies florestais empregando imagens de média resolução espacial}

RESUMO: Essa pesquisa objetivou avaliar as potencialidades de imagens orbitais dos sensores Landsat-8/OLI e Sentinel-2/MSI na distinção de espécies de alguns povoamentos florestais localizados em Campo Belo do Sul, Estado de Santa Catarina. Para tanto, foram alocadas 53 parcelas a campo, nas quais coletou-se a coordenada central da parcela com auxílio de receptores GPS e qual era o indivíduo predominante da parcela, com o maior número de indivíduos. Em ambiente SIG, foram utilizadas duas imagens, uma de cada sensor avaliado, de data próxima a avaliação realizada a campo e com ausência de nuvens e demais fatores atmosféricos. Em seguida, as imagens foram processadas e foram calculados 17 índices de vegetação para cada uma. Os índices foram comparados estatisticamente pelo teste t-Student para amostras independentes. Os índices que proporcionaram a melhor diferenciação das espécies foram: CRI, GNDVI, NDI11, NDI12, NDVI, RDVI, SAVI e SR. Além disso, foi possível perceber que a espécie com maior destaque nas imagens Landsat-8/OLI foi o Eucalyptus spp. ao passo que a Cunninghamia lanceolata (Lamb.) Hooker se diferenciou com maior facilidade nas imagens Sentinel-2. Nesse contexto, foi possível diferenciar as espécies em questão a partir de dados remotamente situados derivados dos sensores Sentinel-2/MSI e Landsat-8/OLI. Contudo, sugere-se que novos estudos utilizando outras fontes de dados de Sensoriamento Remoto e outras espécies sejam avaliadas. 


\section{Introduction}

The forest sector is an important economic activity in Brazil. It acts as a major supplier of raw material to the industrial sectors, and the high levels of productivity of the planted forests in Brazil make the country highly competitive in the foreign market. In addition, this sector also contributes to environmental issues, such as the protection and recovery of water and soil resources, which minimizes the effects caused by greenhouse gas (GHG) emissions and reduces the pressure on native forests (Coutinho et al., 2017).

The diversity of tree species can influence the provision of forest ecosystem services such as timber production, energy and food, carbon sequestration, and regulation of biogeochemical and climate cycles (Assessment, 2005; Gamfeldt et al., 2013). Iverson and McKenzie (2013) state that the complementarity between species can support such services simultaneously. In this sense, information about the diversity of tree species is essential to understand the characteristics and resilience of the forest, as well as the vulnerability to pathogens (Guyot et al., 2015).

Precise species discrimination is important for forest inventory, pest control, and species carbon sequestration assessment, according to Aardt \& Wynne (2007). Therefore, Remote Sensing (SR) techniques have been highlighted in these studies, as orbital images can provide detailed information on the status of the forest, such as species distribution and differentiation, population density, forest extension, and operational monitoring (Purnamasayangsukasih et al., 2016).

The identification of tree species can be considered a classic topic of study within the scope of the optical SR (Holmgren and Thuressopn, 1998; Boyd and Danson, 2005). The spectral reflectance values are used to characterize the stands and differentiate the ages of the species, as researched by Ponzoni et al. (2015) and Goergen et al. (2016).

Several multispectral sensors with different spatial, temporal, and spectral characteristics are available. However, images with lower spatial resolution and, consequently, a greater richness of details are associated with a high acquisition cost and smaller area imaged by the sensor, which restricts its use in analysis of large areas and requires greater periodicity (Alba et al., 2017 ).

In this sense, the use of the Landsat-8/OLI and Sentinel-2/MSI orbital sensors should be tested. Both enable the generation of free data, with medium spatial resolution and accessible temporal resolution. In the case of Sentinel-2/MSI, the spectral capacity is a strong point to be highlighted, due to the inclusion of four bands in the range of the red-edge (red edge), a region of the electromagnetic spectrum very sensitive to the characteristics of vegetation. Thus, these sensors must be studied to fill the gap in the use of high spatial resolution sensors to discriminate forest species.
Given this context, this research aimed to investigate the potential of using orbital images from the Landsat-8/OLI and Sentinel-2/MSI sensors to distinguish species from a forest stand located in Campo Belo do Sul, State of Santa Catarina.

\section{Material and Methods}

The research was carried out in a forest area formed by plantations of Cupressus spp., Pinus elliotti Engelm, Eucalyptus spp., Araucaria angustigolia Kuntze and Cunninghamia lanceolata (Lamb.) Hooker located in the municipality of Campo Belo do Sul, State of Santa Catarina (Figure 1). The area has an average altitude of $1017 \mathrm{~m}$ and the climate, according to the Köppen classification, fits as mesothermal, subtropical humid $\mathrm{Cfb}$ (subtropical), with an average temperature of $15.7^{\circ} \mathrm{C}$ and average annual rainfall is $1647 \mathrm{~mm}$ (Alvares et al., 2013).

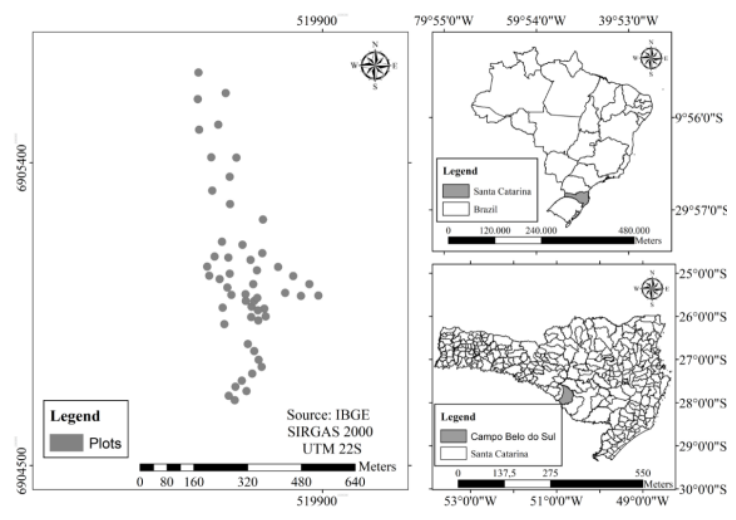

Figure 1. Location of the study area: A) Brazil, B) Santa Catarina and C) study area.

In the stands of the five described species, 53 plots were allocated using GPS receivers (Global Positioning System) of the Garmin Etrex ${ }^{\circledR}$ model to obtain the central coordinate of each plot.

Images from the Landsat- 8 satellites were used, with the OLI sensor (Operational Land Imager) and Sentinel-2 with the MSI sensor (Multispectral Instrument). Landsat-8/OLI has a spatial resolution of 30 meters, a radiometric resolution of 16 bits and a spectral resolution of 8 bands (USGS, 2013). Sentinel-2/MSI has images with 10,20 and 60 meters of spatial resolution, 12 bits of radiometric resolution and 13 spectral bands, with emphasis on the inclusion of red-edge bands (ESA, 2010).

The acquisition of the Landsat-8/OLI image was carried out on the United States Geological Survey website, dated 08/28/2018. The Sentinel-2 / MSI image was obtained from the Copernicus Open Access Hub, dated 9/22/2018. Both images were acquired in orbit 221 and point 79 . The criterion for choosing the images was the absence and / or little 
cloud cover and dates close to the installation of the field plots.

The first digital processing in the images involved the conversion of digital numbers to radiance at the top of the atmosphere and later to reflectance at the base of the Earth's surface using the FLAASH (Fast Line-of-sight Atmospheric Analysis of Hypercubes) algorithm in the computational application ENVI (Environment for Visualizing Images) (EXELIS, 2018).

Then, the vegetation indices (IV) described in Table 1 were derived in the processed images:

Table 1. Vegetation indices calculated for the orbital images referring to the studied forest stands in Campo Belo do Sul/SC.

\begin{tabular}{|c|c|c|c|}
\hline VI & Abbreviation & Formula & Reference \\
\hline Carotenoid & CRI & $1+1$ & Gitelson et al. \\
\hline Reflectance Index & & $\overline{\rho \text { GREEN }}+\overline{\overline{\rho N I R}}$ & (2002) \\
\hline $\begin{array}{l}\text { Green Chlorophyll } \\
\text { Index }\end{array}$ & $\mathrm{CL}_{\text {green }}$ & $\left(\frac{\rho \text { NIR }}{\rho \text { GREEN }}\right)-1$ & $\begin{array}{l}\text { Gitelson et al. } \\
(2003 \mathrm{a}, \mathrm{b})\end{array}$ \\
\hline Enhanced & $\mathrm{EVI}_{2}$ & $5 * \quad(\rho N I R-\rho R E D)$ & Jiang et al. \\
\hline Vegetation Index 2 & & $2,5^{*} \overline{\left(\rho \mathrm{NIR}+2,4^{*} \rho \mathrm{RED}+1\right)}$ & $(2008)$ \\
\hline $\begin{array}{l}\text { Green Normalized } \\
\text { Difference }\end{array}$ & GNDVI & $\frac{\rho N I R-\rho \text { GREEN }}{\rho N I R+\rho \text { GREEN }}$ & $\begin{array}{l}\text { Gitelson et al. } \\
\text { (1996) }\end{array}$ \\
\hline $\begin{array}{l}\text { Vegetation Index } \\
\text { Infrared Simple } \\
\text { Ratio }\end{array}$ & ISR & $\frac{\rho \mathrm{NIR}}{\rho \mathrm{SWIR} 1}$ & $\begin{array}{l}\text { Fernandes et al. } \\
\qquad(2003)\end{array}$ \\
\hline $\begin{array}{l}\text { Modified Soil } \\
\text { Ajusted Vegetation } \\
\text { Index }\end{array}$ & MSAVI & $\frac{\rho N I R-\rho R E D}{\rho N I R+\rho R E D+L}(1+L)$ & Qi et al. (1994) \\
\hline Modified Soil & $\mathrm{MSAVI}_{2}$ & $2 \rho \mathrm{NIR}+1-\sqrt{2(\rho \mathrm{NIR}+1)^{2}}-8(\rho \mathrm{NIR}-\rho \mathrm{RED})$ & Qi et al. (1994) \\
\hline $\begin{array}{l}\text { Ajusted Vegetation } \\
\text { Index } 2\end{array}$ & & $\begin{array}{ll}2 \\
\end{array}$ & \\
\hline Modified Simple & MSR & $(\rho N I R / \rho R E D)-1$ & Chen (1996) \\
\hline Ratio Index & & $\sqrt{\sqrt{\rho \mathrm{NIR} / \rho \mathrm{RED}+1}}$ & \\
\hline $\begin{array}{l}\text { Modified Triangular } \\
\text { Vegetation Index }\end{array}$ & MTVI & $\begin{array}{c}1,2 *(1,2 * \rho N I R-\rho G R E E N)-2,5 * \rho R E D- \\
\rho G R E E N)\end{array}$ & $\begin{array}{l}\text { Haboudane et } \\
\text { al. (2004) }\end{array}$ \\
\hline Normalized & NDI11 & $\rho N I R-\rho S W I R 1$ & Hardisky et al. \\
\hline $\begin{array}{l}\text { Difference Infrared } \\
\text { Index }\end{array}$ & & $\overline{\rho N I R+\rho S W I R 1}$ & (1983) \\
\hline $\begin{array}{l}\text { Normalized Burn } \\
\text { Ratio }\end{array}$ & NDI12 & $\frac{\rho N I R-\rho S W I R 2}{\rho N I R+\rho S W I R 2}$ & $\begin{array}{l}\text { Key et al. } \\
\text { (2002) }\end{array}$ \\
\hline $\begin{array}{l}\text { Normalized } \\
\text { Difference }\end{array}$ & NDVI & $\frac{\rho N I R-\rho R E D}{\rho N I R+\rho R E D}$ & $\begin{array}{l}\text { Rouse et al. } \\
\text { (1974) }\end{array}$ \\
\hline $\begin{array}{c}\text { Vegetation Index } \\
\text { Optimized Soil } \\
\text { Adjusted Vegetation } \\
\text { Index }\end{array}$ & OSAVI & $\frac{\rho \text { NIR }-\rho \text { RED }}{(\rho N I R+\rho \text { RED }+1,6) * 1,16}$ & $\begin{array}{l}\text { Rondeaux et al. } \\
\text { (1996) }\end{array}$ \\
\hline $\begin{array}{l}\text { Plant Senescence } \\
\text { Reflectance Index }\end{array}$ & PSRI & $\frac{\rho R E D-\rho B L U E}{\rho N I R}$ & $\begin{array}{l}\text { Merzyak et al. } \\
\quad(1999)\end{array}$ \\
\hline $\begin{array}{c}\text { Re-mormalized } \\
\text { Difference } \\
\text { Vegetation Index }\end{array}$ & RDVI & $\frac{\rho N I R-\rho R E D}{\sqrt{\rho N I R+\rho R E D}}$ & $\begin{array}{l}\text { Wang et al. } \\
\text { (1998) }\end{array}$ \\
\hline Soil Ajusted & SAVI & $(1+L)(\rho N I R-\rho R E D)$ & Huete (1988) \\
\hline $\begin{array}{l}\text { Vegetation Index } \\
\text { Simple Ratio }\end{array}$ & SR & $\begin{array}{c}\rho N I R+\rho R E D+L \\
\frac{\rho N I R}{\rho R E D}\end{array}$ & Jordan (1969) \\
\hline
\end{tabular}

Where: $\rho$ BLUE: Blue band reflectance; $\rho$ GREEN: Green band reflectance; $\rho$ RED: Red band reflectance; $\rho$ NIR: Reflectance of the near infrared band; $\rho$ SWIR: Reflectance of the short wave infrared band; L: constant that minimizes the effects of the soil, used in this study the value of $0.50 ; \gamma=$ slope of the ground line. 
Statistical analyzes involved the normality test using the Shapiro-Wilk test at 5\% probability. The design was completely randomized with four treatments (reflectance obtained from the visible and infrared bands of Landsat-8/OLI (T1), reflectance derived from the vegetation indices from Landsat- 8 /OLI (T2), reflectance obtained from the bands of the visible and infrared of Sentinel-2/MSI (T3), reflectance derived by vegetation indexes from Sentinel-2/MSI (T4) and 53 repetitions (plots installed in the field). Then, the data were submitted to the T-Student test for independent samples, in order to assess the differences between the mean values of the IVs and spectral bands derived from Landsat-8/OLI and Sentinel-2/MSI. All analyzes were performed using software $\mathrm{R}$ version 3.4.1. ( $\mathrm{R}$ Core Team, 2020).

Table 2. Descriptive statistics and significance of the spectral values derived from the Landsat-8/OLI and Sentinel2/MSI sensors.

\begin{tabular}{ccc}
\hline VI & Landsat-8/OLI & Sentinel-2/MSI \\
\hline Clgreen & $0.7307+/-0.0830$ & $2.2512+/-0.5109^{\text {ns }}$ \\
CRI & $0.8861+/-0.3876$ & $0.0217+/-0.0022^{* *}$ \\
EVI2 & $0.8341+/-0.2166$ & $0.0379+/-0.0081^{\text {ns }}$ \\
GNDVI & $0.2946+/-0.0934$ & $0.5220+/-0.0573^{* *}$ \\
ISR & $9.7349+/-2.5120$ & $1.8616+/-9.4629^{\text {ns }}$ \\
MSAVI & $0.2309+/-0.0507$ & $0.0298+/-0.0062^{\text {ns }}$ \\
MSAVI2 & $-0.8643+/-0.1095$ & $-1.4690+/-0.0067^{\text {ns }}$ \\
MSR & $1.0573+/-0.3134$ & $1.5731+/-1.3320^{\text {ns }}$ \\
MTVI & $-2.2012+/-1.6895$ & $0.0044+/--2.0058^{\text {ns }}$ \\
NDI1 & $0.8011+/-0.0572$ & $0.2798+/-0.1222^{* *}$ \\
NDI2 & $0.9633+/-0.0168$ & $0.5684+/-0.1260^{* *}$ \\
NDVI & $0.5060+/-0.1084$ & $0.6440+/-0.0772^{* *}$ \\
OSAVI & $0.4500+/-0.1035$ & $0.0112+/-0.0024^{\text {ns }}$ \\
PSRI & $-0.4910+/-0.1111$ & $-0.1696+/-0.0433^{* *}$ \\
RDVI & $1.1678+/-0.2945$ & $0.1000+/-1.0159^{* *}$ \\
SAVI & $0.0005+/-0.0001$ & $0.0298+/-0.0062^{* *}$ \\
SR & $3.1632+/-0.9015$ & $4.9210+/-3.1666^{* *}$ \\
\hline
\end{tabular}

Where: ns: non significant; **: significant by the T-Student test for independent samples at $5 \%$ probability; IV: vegetation index.

Such results can be explained by the leaf characteristics of the species evaluated. Souza et al. (2020) point out tha leaf structures are influencing factors on the spectral properties of plants. As a result, it is worth understanding the dynamics that occur between vegetation and electromagnetic radiation, resulting in the processes of absorption, reflection and transmission.

The CRI, GNDVI, NDI11, NDI12, NDVI, RDVI, SAVI and SR indices, which values differed between the two sensors tested, point to the direct relationship between the bands of the visible region (green and red), near infrared and medium infrared spectral phenomena mentioned above.The studies carried out by Goodwin et al. (2005) and Canavesi

\section{Results and discussion}

The Table 2 illustrates the results obtained from the statistical tests performed. They demonstrate that the spectral data derived from Landat-8/OLI and Sentinel-2/MSI differed significantly, at $5 \%$ probability: 
heterogeneity, with individuals in different stages of growth. This fact can be seen in Figure 2:

A)

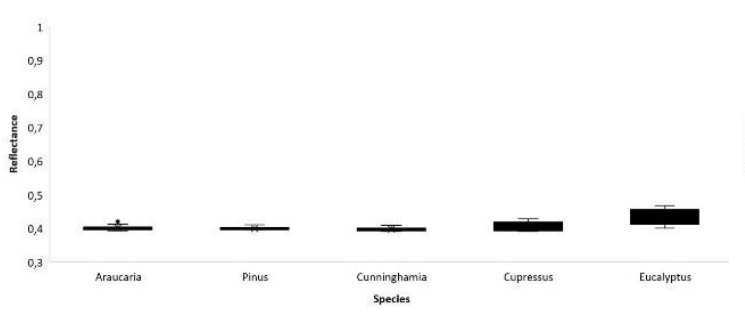

B)

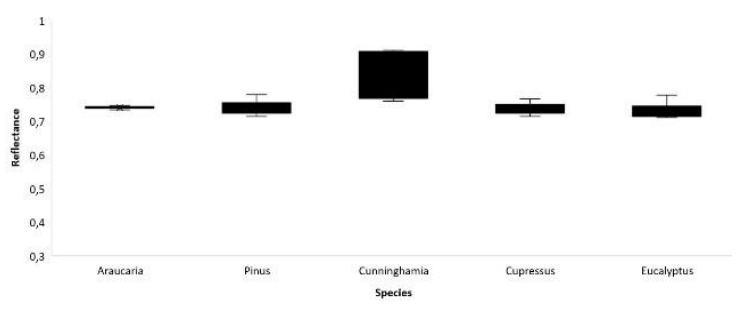

Figure 2. Reflectance of the species evaluated with data: A) Landsat-8/OLI and B) Sentinel-2/MSI.

Figure 2 highlights that, for the data derived from Sentinel-2/MSI, there was species differentiation caused by the greater variation in the reflectance values, with emphasis on the plots with a predominance of individuals of $C$. lanceolata. The commercial species also stood out from the others,

A)

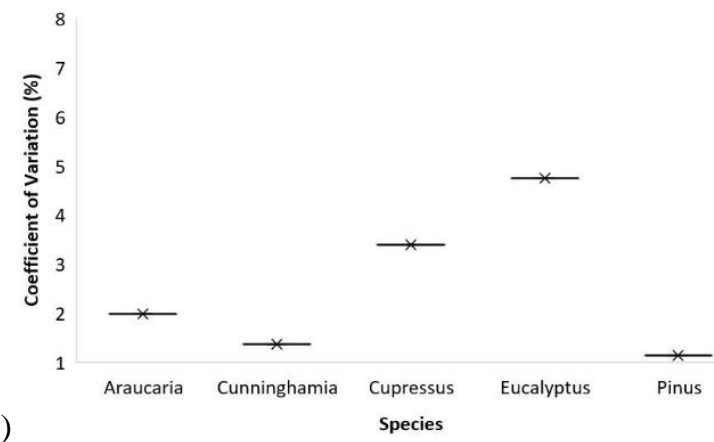

In general, it is noticed that the results (reflectance and coefficient of variation) of the Sentinel-2/MSI sensor present higher values than the Landsat-8/OLI data. This can be explained by the differences in the technical properties of the tested sensors, especially in the resolutions (temporal, spatial, radiometric and spectral), modes of image acquisition and other specific factors. In addition, these values reflect only the date of image acquisition (08/28/2018 and 09/22/2018) and indicate that a temporal evolution could assist in differentiating species from images of medium spatial resolution.

Sheeren et al. (2016) studied the potential of Sentinel-2/MSI images for the distinction of species in temperate forests and concluded that the dominant trees showed greater accuracy in the classification and that the inclusion of phenological factors can improve the identification of species.

In this theme, the vegetation indices combined with the spectral attributes of the image can contribute to the distinction of species using since the genus Cupressus spp. differed slightly from A. angustigolia. The spectral responses of Landsat8/OLI showed more uniform values and greater distinction between the genera Cupressus spp. and Eucalyptus spp., as shown in Figure 3:

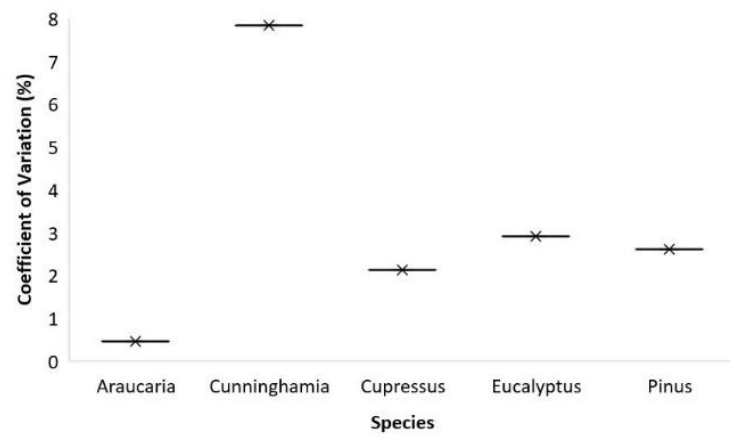

images of medium spatial resolution, since the plots with predominance of $P$. elliotti and Eucalyptus spp. had a greater relationship with vegetation indexes with significant results in statistical tests. However, the discrimination of the other species was not assertive and showed several built-in errors, especially due to the structural and biophysical conditions of these individuals.

The level of differentiation by image is also a factor of interest, since the differentiation of species of distinct genera and characteristics can be more complex than the identification of species of the same genus. Goergen et al. (2016) evaluated the possibility of using Landsat-5/TM images to differentiate species of Eucalyptus dunnii and Eucalyptus urograndis with different ages and concluded that such data were successful in distinguishing the species tested and also of the same species in equi-plantations. Similar analysis was performed by Alba et al. (2017), in which the $E$. grandis growth stages were differentiated using data from Landat-8/OLI. 


\section{Conclusions}

It was possible to differentiate tree species from remotely located data derived from the Sentinel-2/MSI and Landsat-8/OLI sensors. The greatest assertiveness was in the differentiation of commercial species (Pinus spp. and Eucalyptus spp.) of the other species evaluated.

\section{References}

Alvares CA, Stape JL, Sentelhas PC, Gonçalves JLM, Sparovek G (2013) Köppen's climate classification map for Brazil. Meteorologische Zeitschrift, 22 (6):711-728. doi: 10.1127/09412948/2013/0507.

Alba E. Marchesan J, Mello EP, Tramontina J, Silva EA, Pereira RS (2017) Uso de imagens de média resolução espacial para o monitoramento de dósseis de Eucalyptus grandis. Scientia Agraria, 18 (4):1-8.

Aardt JAN van, Wynne, RH (2007) Examining pine spectral separability using hyperspectral data from an airborne sensor: an extension of field-based results. International Journal of Remote Sensing, 28: 431-436. DOI: 10.1080/01431160500444772.

Assessment, ME (2005) Ecosystems \& Human Well-Being: Synthesis; Island Press: Washington, DC, USA;

Boyd DS, Danson FM (2005) Satellite remote sensing of forest resources: Three decades of research development. Progress in Physical Geography, 29: 1-26.

Canavesi V, Ponzoni FJ (2010) Caracterização espectral de plantios de Eucalyptus utilizando dados Hyperion EO-1 e SRTM. Ambiência, 6:127-136.

Coutinho VM, Corte APD, Sanquetta CR, Hentz AMK, Eisfeld RL, Nascimento FAF (2017) Mapeamento das áreas plantadas com Eucalyptus spp. no estado do Paraná. Biofix Scientific Journal, 2(1): 32-43.

Chen JM (1996) Evaluation of vegetation indices and modified simple ratio for boreal applications. Canadian Journal of Remote Sensing, 22: 229-242.

Esa. European Space Agency. GMES Sentinel-2 Mission required document. Disponível em: http://esamultimedia.esa.int/docs/GMES/Sentinel2/MRD.pdf. Acesso em: 22 mar 2020.

Fernandes RA, Butson CB, Leblanc SG, Latifovic, R. Landsat-5 TM and derived from SPOT-4 Vegetation data. Canadian Journal of Remote Sensing, 29: 241-258.
It is important to highlight the importance of conducting tests with sensor images with higher spatial resolution and other vegetation indexes to contribute to the identification of forest species using data remotely located.

Gamfeldt L, Snall T, Bagchi R, Jonsson M, Gustafsson L, Kjellander P, Ruiz-Jaen MC, Fröberg M, Stendahl J, Philipson CD, et al. (2013). Higher levels of multiple ecosystem services are found in forests with more tree species. Nature Communications (4), 1340.

Gitelson AA, Kaufman YJ, Merzlyak MN (1996) Use of a green channel in remote sensing of global vegetation from EOS-MODIS. Remote Sensing of Environment, 58: 289-298.

Gitelson AA, Zur Y, Chivkunova OB, Merzlyak MN (2002) Assessing carotenoid content in plant leaves with reflectance spectroscopy. Photophysical and Photochemical, 75: 272-281.

Gitelson AA, Verma SB, VI, A. A.; Rundquist DC, Keydan G, Leavitt B, Arkebauer TJ, Burba GG, Suyker, AE (2003) Novel technique for remote estimation of $\mathrm{CO} 2$ flux in maize. Geophysical Research Letters, 30: 1486-1489.

Gitelson AA, VI, A. A.; Arkebauer TJ, Rundquist DC, Keydan G, Leavitt B (2003) Remote estimation of leaf area index and green leaf biomass in maize canopies. Geophysical Research Letters, 30: 12481251 .

Goergen LCDG, Kilca RDV, Narvaes, I.D, Silva MN, Silva EA, Pereira RS, Adami M (2016) Distinção de espécies de eucalipto de diferentes idades por meio de imagens TM/Landsat-5. Pesquisa Agropecuária Brasileira, Brasília, (51), 1: 53-60.

Guyot, V.; Castagneyrol, B.; Vialatte, A.; Deconchat, M.; Selvi, F.; Bussotti, F.; Jactel, H. Tree diversity limits the impact of an invasive forest pest. PLoS ONE 2015, 10, e0136469.

Haboudane D, Miller JR, Pattey E, Zarco-Tejada P J, Strachan IB (2004) Hyperspectral vegetation indices and novel algorithms for predicting green LAI of crop canopies: Modeling and validation in the context of precision agriculture. Remote Sensing of Environment, 90: 337-352.

Hardisky M, Klemas V, Smart R (1983) The Influences of Soil Salinity, Growth Form, and Leaf Moisture on the Spectral Reflectance of Spartina Alterniflora Canopies. Photogrammetric Engineering and Remote Sensing, 49: 77-83. 
Holmgren P, Thuressopn T (1998) Satellite remote sensing for forestry planning - A review. Scandavian Journal of Forest Research, 13: 90-110.

Huete AR (1988) A soil vegetation adjusted index (SAVI). Remote Sensing of Environment, 25: 295309.

Huete A, Didan K, Miura T, Rodriguez EP, Gao X, Ferreira LG (2002) Overview of the radiometric and biophysical performance of the MODIS vegetation indices. Remote Sensing of Environment, 83(12):195-213.

Iverson LR, McKenzie D (2013) Tree-species range shifts in a changing climate: Detecting, modeling, assisting. Landscape Ecology, 28:879-889.

Jiang Z, Huete AR, Didan K, Miura T (2008) Development of a two-band enhanced vegetation index without a blue band. Remote Sensing of Environment, 112: 3833-3845.

Jordan CF (1969) Derivation of leaf-area index from quality of light on the forest floor. Ecology, 50(406): 663-666.

Key CH, Zhu Z, Ohlen D, Howard S, Mckinley R, Benson N (2002) The normalized burn ratio and relationships to burn severity: ecology, remote sensing and implementation. In J. D. Greer (Ed.), Rapid Delivery of Remote Sensing Products. Proceedings of the Ninth Forest Service Remote Sensing Applications Conference, San Diego, CA 812 April, 2002. Bethesda: American Society for Photogrammetry and Remote Sensing.

Merzlyak MN, Gitelson AA, Chivkunova OB, Rakitin YR (1999) Non-destructive optical detection of pigment changes during leaf senescence and fruit ripening. Plant Physiology, 106: 135-141

Ponzoni FJ, Pacheco LRF, Santos SB, AndradesFilho CO (2015) Caracterização espectrotemporal de dosséis de Eucalyptus spp. mediante dados radiométricos TM/Landsat5. Cerne, 2(2): 267-275.

Purnamasayangsukasih RP, Norizah K, Ismail AMA, Shamsudin I (2016) A review of uses of satellite imagery in monitoring mangrove forests. IOP Conf. Series: Earth and Environmental Science, 37.

Qi J., Kerr Y., Chehbouni A., 1994. External factor consideration in vegetation index development. Proc. of Physical Measurements and Signatures in Remote Sensing, ISPRS, 723-730.

R Core Team (2020). R: A language and environment for statistical computing. R Foundation for Statistical Computing, Vienna, Austria. URL https://www.R-project.org/.

Rondeaux G, Steven M, Baret F (1996) Optimization of soil-adjusted vegetation indices, Remote Sensing of Environment, 55:95-107.

Rouse JW, Haas RH, Schell JA (1974) Monitoring the Vernal Advancement of Retrogradation (Green Wave Effect) of Natural Vegetation, Remote Sensing Center, Texas A\&M University College Station, USA.

Sheeren D, Fauvel M, Josipovic V, Lopes M, Planque C, Willm J, Dejoux FF (2016) Tree Species Classification in Temperate Forests Using Formosat2 Satellite Image Time Series. Remote Sensing, 8, 734; doi:10.3390/rs8090734.

Souza, IV, Duarte, VBR, Silva FDCSD, Silva MC, Sousa HGDA, Gomes JNN, Giongo M, Batista AC (2020) Veículos aéreos não tripulados e sensores remotos: ferramentas para o gerenciamento dos recursos florestais. Journal of Biotechnology and Biodiversity, (8), 2: 148-157.

Wang K, Shen ZQ, Wang RC (1998) Effects of nitrogen nutrition on the spectral reflectance characteristics of rice leaf and canopy. Journal of Zhejiang University, 24:93-97.

Yang Q, Duan ZB, Wang ZL, He KH, Sun QX, Peng ZH (2008) Bamboo resources, utilization and ex-situ conservation in Xishuangbanna, South-eastern China. Journal of Forestry Research, 19(1): 79-83. doi: 10.1007/s11676-008-0015-6. 